\title{
Synthesis of Some New Functionalized Bis-thiazolidin-5-one and Bis-thiazolidin-4-one Derivatives
}

\author{
M. A. Metwally", A. Fekri, N. Nagy, F. A. Amer \\ Chemistry Department, Faculty of Science, MansouraUniversity, 35561, Mansoura, Egypt
}

\begin{abstract}
A series of bis-thiazolidin-5-one and bis-thiazo lid in-4-one derivatives $\mathbf{3}$ and $\mathbf{5}$ was prepared by the treatment of highly functional thiocarbamoyl intermediates 2 and 4 with chloroacetyl chloride and chloroacetic acid, respectively. Treatment of the bis-thiocarbamoyl derivative 4a with diazotized sulphanilic acid affected acetyl cleavage to afford the corresponding arylhydrazono-thiocarbamoyl derivative 6.The title compounds bis-thiazolidin-5-one and bis-thiazolidin-4-one derivatives showed high reactivity towards azo coupling reaction with diazotized sulphanilic acid and Knoevenagel reaction with 4-isopropylbenzaldehyde.
\end{abstract}

Keywo rds Thiocarbamoyl, Ch loroacetyl chloride, Bis-thiazo lidin-5(and 4-)-ones, Japp-Kling mann Reaction

\section{Introduction}

The chemistry of thiazole derivatives, including new methodologies for their preparation, and recent applications, such as their growing use in organic synthesis in the biological field and asymmetric catalys is as ligands has been recently reviewed[1]. Thiazolidinones are known mainly as biologically active compounds with a broad range of activity and as intermediates in the synthesis of antibiotics and dyes[2-4]. Several papers have been published on the use of these compounds as antimicrobial[5,6], antifungal[7,8], anti-inflammatory activity[9], anticonvulsant[10], anesthetic [11] and antiviral drugs[12]. 2-Aminothiazoles and its derivatives are also used in the syntheses of various types of dyes[13-16]. In this work, a series of bis-thiazolidin-5-one and bis-thiazolidin-4-one derivatives was prepared by treatment of their corresponding thiocarbamoyl intermediates with chloroacetyl chloride and chloroacetic acid, respectively. Also, the reactions of title compounds bis-thiazolidin-one derivatives with diazotized sulphanilic acid and with 4-isopropylbezaldehyde were studied.

\section{Materials and Methods}

All melting points were measured on an electrothermal Gallenkamp melting apparatus. Elemental analyses were

* Corresponding author:

mamegs@mans.edu.eg (M. A. Metwally)

Published online at http://journal.sapub.org/chemistry

Copyright (C) 2012 Scientific \& Academic Publishing. All Rights Reserved carried out at the Microanalytical Unit, Faculty of Science, University of Mansoura, Egypt; the results were in satisfactory agreement with the calculated values. IR spectra $(\mathrm{KBr})$ were determined on a Mattson 5000 FTIR spectrometer (not all frequencies are reported). Mass spectra were obtained at a Finnigan MAT 212 instrument (electron impact: $70 \mathrm{eV})$.

The title compound 1 was prepared by boiling a hot solution of ethyl acetoacetate $(7.6 \mathrm{ml}, 0.06 \mathrm{~mol})$ in $30 \mathrm{ml}$ dry xylene with a hot solution of benzidine $(5.5 \mathrm{~g}, 0.03 \mathrm{~mol})$ in dry xylene $(30 \mathrm{ml})$. The precipitate that formed on cooling was filtered off, dried and recrystallized from ethanol to give compound 1 as buff crystals, m.p. $=230-232^{\circ} \mathrm{C}$, y ield $=$ 85\%. IR ( $\left./ \mathrm{cm}^{-1}\right)$ : $3356(\mathrm{NH}), 1668(\mathrm{C}=\mathrm{O}), 1633(\mathrm{C}=\mathrm{O})$. Elemental analysis: Calc. for $\mathrm{C}_{20} \mathrm{H}_{20} \mathrm{O}_{4} \mathrm{~N}_{2}$ (352.38): $\mathrm{C}=$ $68.16, \mathrm{H}=5.72, \mathrm{~N}=7.95 \%$. Found: $\mathrm{C}=68.29, \mathrm{H}=5.81, \mathrm{~N}=$ $7.88 \%$.

Synthes is of N,N'-([1, 1'-biphenyl]-4,4'-diy l)-bis-(3-o xo -2 -(5-o xo-3-phenyl-thiazo lid in-2-ylidene)butanamide) (3)

To a cold suspension of finely divided $\mathrm{KOH}(0.78 \mathrm{~g}, 14$ $\mathrm{mmol})$ in DMF (20 ml) was added the title co mpound1 (2.46 $\mathrm{g}, 7 \mathrm{mmol})$ followed by phenyl is othiocyanate $(1.68 \mathrm{ml}, 14$ mmol). The mixture was stirred at room temperature overnight, and then treated with chloroacetyl chloride (1.12 $\mathrm{ml}, 14 \mathrm{mmol}$ ). The stirring was continued at room temperature for 8 hours. The reaction mixture was poured into ice-cold water. The resultant solid product was collected by filtration, washed with water, dried, and recrystallized from ethanol. m.p. $=223-225^{\circ} \mathrm{C}$, yield $=72 \%$. IR $\left(\mathrm{v} / \mathrm{cm}^{-1}\right)$ : $3356(\mathrm{NH}), 1730(\mathrm{C}=\mathrm{O}), 1660(\mathrm{C}=\mathrm{O}), 1633(\mathrm{C}=\mathrm{O}) . \mathrm{MS}: \mathrm{m} / \mathrm{z}$ $=702\left(\mathrm{M}^{+}, 20\right), 400$ (30), 298 (45), 226 (83), 103 (75). Elemental analysis: Calc. for $\mathrm{C}_{38} \mathrm{H}_{30} \mathrm{~N}_{4} \mathrm{O}_{6} \mathrm{~S}_{2}$ (702.8): $\mathrm{C}=$ 
$64.94, \mathrm{H}=4.30, \mathrm{~N}=7.97 \%$. Found: $\mathrm{C}=65.08, \mathrm{H}=4.24, \mathrm{~N}=$ $7.89 \%$.

$\mathrm{N}, \mathrm{N}^{\prime}$-([1,1'-biphenyl]-4,4'-diy 1)-bis-(2-(aryl-thiocarba moy 1)-3-oxo-butanamide) derivatives (4)

To a cold suspension of finely divided $\mathrm{KOH}(0.78 \mathrm{~g}, 14$ $\mathrm{mmol})$ in DMF $(20 \mathrm{ml})$ were added the title compound 1 $(2.46 \mathrm{~g}, 7 \mathrm{mmol})$ fo llowed by phenyl isothiocyanate $(1.68 \mathrm{ml}$, $14 \mathrm{mmol})$. The reaction mixture was stirred at room temperature overnight, poured into ice-cold water, and then neutralized with dilute $\mathrm{HCl}$. The resultant solid product was collected by filtration, washed with water, dried, and recrystallized from ethanol to afford compounds $4 \mathrm{a}$ and $4 \mathrm{~b}$.

(4a): m.p. $=133-135^{\circ} \mathrm{C}$, yield $=65 \%$. IR $\left(v / \mathrm{cm}^{-1}\right)$ : 3344(NH), $3202(\mathrm{NH}), 1665(\mathrm{C}=\mathrm{O}), 1610(\mathrm{C}=\mathrm{N})$. Elemental analysis: Calc. for $\mathrm{C}_{34} \mathrm{H}_{30} \mathrm{~N}_{4} \mathrm{O}_{4} \mathrm{~S}_{2}$ (622.76): $\mathrm{C}=65.57, \mathrm{H}=$ 4.86, $\mathrm{N}=9.00 \%$. Found: $\mathrm{C}=65.33, \mathrm{H}=4.77, \mathrm{~N}=8.89 \%$.

(4b): m.p. $=119-120^{\circ} \mathrm{C}$, y ield $=78 \%$. IR $\left(v / \mathrm{cm}^{-1}\right)$ : $3367(\mathrm{NH}), 3211(\mathrm{NH}), 1660(\mathrm{C}=\mathrm{O}), 1607(\mathrm{C}=\mathrm{N}) . \mathrm{MS}: \mathrm{m} / \mathrm{z}=$ $526\left(\mathrm{M}^{+}, 15\right), 311(25), 195$ (40), 131 (90), 60 (100), $55(53)$. Elemental analysis: Calc. for $\mathrm{C}_{26} \mathrm{H}_{30} \mathrm{~N}_{4} \mathrm{O}_{4} \mathrm{~S}_{2}$ (526.67): $\mathrm{C}=$ $59.29, \mathrm{H}=5.74, \mathrm{~N}=10.64 \%$. Found: $\mathrm{C}=59.41, \mathrm{H}=5.88, \mathrm{~N}$ $=10.73 \%$.

Synthes is of N,N'-([1,1'-biphenyl]-4,4'-diy l)-bis-(3-o xo-2 -(4-o xo-th iazo lid in-2-ylidene)-butanamide) derivatives (5)

A mixture of bis-thiocarbamoyl4 $(3 \mathrm{mmol})$ and choloroacetic acid $(0.57 \mathrm{~g}, 6 \mathrm{mmol})$ was refluxed for $4-6$ hours in glacial acetic acid $(30 \mathrm{ml})$ containing fused sodium acetate $(0.5 \mathrm{~g}, 6 \mathrm{mmol})$. The reaction mixture was cooled and poured into cooled water. The solid precipitate that formed was filtered off, dried and recrystallized from ethanol to afford the bis-thiazolidin-4-one derivatives $\mathbf{5}$.

(5a): m.p. $>310^{\circ} \mathrm{C}$, yield $=74 \%$. IR $\left(v / \mathrm{cm}^{-1}\right): 3410(\mathrm{NH})$, $1715(\mathrm{C}=\mathrm{O}), 1632(\mathrm{C}=\mathrm{O})$. MS: $\mathrm{m} / \mathrm{z}=702\left(\mathrm{M}^{+}, 10\right), 386(23)$, 236 (40), 158 (55), 73 (80), 50 (100). Elemental analysis: Calc. for $\mathrm{C}_{38} \mathrm{H}_{30} \mathrm{~N}_{4} \mathrm{O}_{6} \mathrm{~S}_{2}(702.8): \mathrm{C}=64.94, \mathrm{H}=4.30, \mathrm{~N}=$ 7.97\%. Found: $\mathrm{C}=64.83, \mathrm{H}=4.36, \mathrm{~N}=7.88 \%$.

(5b): m.p. $>312^{\circ} \mathrm{C}$, y ield $=70 \%$. IR $\left(v / \mathrm{cm}^{-1}\right): 3434(\mathrm{NH})$, $1714(\mathrm{C}=\mathrm{O}), 1631(\mathrm{C}=\mathrm{O}) \cdot \mathrm{MS}: \mathrm{m} / \mathrm{z}=606\left(\mathrm{M}^{+}, 10\right), 213(14)$, 133 (25), 106 (52), 57 (100). Elemental analysis: Calc. for $\mathrm{C}_{30} \mathrm{H}_{30} \mathrm{~N}_{4} \mathrm{O}_{6} \mathrm{~S}_{2}$ (606.71): $\mathrm{C}=59.39, \mathrm{H}=4.98, \mathrm{~N}=9.23 \%$. Found: $\mathrm{C}=59.58, \mathrm{H}=5.05, \mathrm{~N}=9.32 \%$.

Reaction of bis-thiocarbamoyl derivative $4 a$ with diazotized sulphanilic acid Formation of (6)

A solution of compound $4 \mathrm{a}(2.48 \mathrm{~g}, 4 \mathrm{mmol})$ in ethanol $(20 \mathrm{ml})$ and sodium acetate $(1.5 \mathrm{~g})$ was stirred in an ice - bath at $0-5^{\circ} \mathrm{C}$. Diazotized solution of sulphanilic acid $(1.38 \mathrm{~g}, 8$ mmol) was added to stirred solution over a period of 30 minutes and the stirring was continued for 2 hours with cooling. The reaction mixture was left in ice - bath and the formed solid product was filtered off, dried and recrystallized from ethanol to afford compound 6.m.p. > $350^{\circ} \mathrm{C}$, yield $=71 \%$. IR $\left(\mathrm{v} / \mathrm{cm}^{-1}\right): 3326(\mathrm{NH}), 3216(\mathrm{NH})$, $1631(\mathrm{C}=\mathrm{O}) . \mathrm{MS}: \mathrm{m} / \mathrm{z}=907\left(\mathrm{M}^{+}, 10\right), 382(20), 193(40)$, 113 (44), 58 (57), 55 (100). Elemental analysis: Calc. for $\mathrm{C}_{42} \mathrm{H}_{34} \mathrm{~N}_{8} \mathrm{O}_{8} \mathrm{~S}_{4}$ (907.03): $\mathrm{C}=55.62, \mathrm{H}=3.78, \mathrm{~N}=12.35 \%$. Found: $\mathrm{C}=55.40, \mathrm{H}=3.85, \mathrm{~N}=12.41 \%$.

Formation of compounds 7 and 8
The diazotized solution of sulphanilic acid $(0.69 \mathrm{~g}, 2$ mmol) was added with continuous stirring to a cold solution of compound 3 or compound $5 \mathrm{a}(4 \mathrm{mmol})$ in $20 \mathrm{ml}$ ethanol containing sodiumacetate $(0.75 \mathrm{~g})$. The reaction mixture was stirred at $0-5^{\circ} \mathrm{C}$ for 2 hours, left to stand at room te mperature. The solid product that obtained was filtered off, dried and recrystallized from ethanol to afford compound 7 or compound $\mathbf{8}$, respectively.

(7): m.p. $=235-237^{\circ} \mathrm{C}$, yield $=73 \%$. IR $\left(v / \mathrm{cm}^{-1}\right): 3430$ $(\mathrm{NH}), 1688(\mathrm{C}=\mathrm{O}), 1657(\mathrm{C}=\mathrm{O}) . \mathrm{MS}: \mathrm{m} / \mathrm{z}=1071\left(\mathrm{M}^{+}, 15\right)$, 974 (18), 408 (25), 271 (33), 120 (63), 58 (100), 53 (66). Elemental analysis: Calc. for $\mathrm{C}_{50} \mathrm{H}_{38} \mathrm{~N}_{8} \mathrm{O}_{12} \mathrm{~S}_{4}$ (1071.14): $\mathrm{C}=$ $56.06, \mathrm{H}=3.58, \mathrm{~N}=10.46 \%$. Found: $\mathrm{C}=56.32, \mathrm{H}=3.62, \mathrm{~N}$ $=10.24 \%$.

(8): m.p. $>320^{\circ} \mathrm{C}$, yield $=76 \%$. IR $\left(\mathrm{v} / \mathrm{cm}^{-1}\right): 3395(\mathrm{NH})$, $1673(\mathrm{C}=\mathrm{O}), 1633(\mathrm{C}=\mathrm{O}) . \mathrm{MS}: \mathrm{m} / \mathrm{z}=1071\left(\mathrm{M}^{+}, 5\right), 980(23)$, 311 (33), 135 (55), 79 (100), 65 (73). Elemental analysis: Calc. for $\mathrm{C}_{50} \mathrm{H}_{38} \mathrm{~N}_{8} \mathrm{O}_{12} \mathrm{~S}_{4}(1071.14): \mathrm{C}=56.06, \mathrm{H}=3.58, \mathrm{~N}=$ $10.46 \%$. Found: $\mathrm{C}=56.18, \mathrm{H}=3.46, \mathrm{~N}=10.37 \%$.

Formation of compounds 9 and 10

A mixture of $b$ is-thiazolidin-5-one derivative 3 or bis-thiazolidin-4-one derivative $5 \mathrm{a}(3 \mathrm{mmol})$ and 4-isopropylbenzaldehyde $(0.9 \mathrm{ml}, 6 \mathrm{mmol})$ was refluxed for 4 hours in ethanol $(30 \mathrm{ml})$ containing catalytic amount of piperidine. The solid products that formed on cooling were filtered off, dried and recrystallized from ethanol to afford the corresponding arylidene derivatives 9 or 10 , respectively.

(9): $\mathrm{m}, \mathrm{p} .=310-312^{\circ} \mathrm{C}$, yield $=78 \%$. IR $\left(\mathrm{v} / \mathrm{cm}^{-1}\right): 3362$ $(\mathrm{NH}), 1678(\mathrm{C}=\mathrm{O}), 1654(\mathrm{C}=\mathrm{O}) . \mathrm{MS}: \mathrm{m} / \mathrm{z}=963\left(\mathrm{M}^{+}, 30\right)$, 893 (45), 507 (35), 210 (40), 184 (100). Elemental analysis: Calc. for $\mathrm{C}_{58} \mathrm{H}_{50} \mathrm{~N}_{4} \mathrm{O}_{6} \mathrm{~S}_{2}(963.17): \mathrm{C}=72.33, \mathrm{H}=5.23, \mathrm{~N}=$ $5.82 \%$. Found: $\mathrm{C}=72.44, \mathrm{H}=5.27, \mathrm{~N}=5.70 \%$.

(10): m.p. $>350^{\circ} \mathrm{C}$, y ield $=73 \%$. IR $\left(v / \mathrm{cm}^{-1}\right): 3380(\mathrm{NH})$, $1666(\mathrm{C}=\mathrm{O}), 1643(\mathrm{C}=\mathrm{O}) . \mathrm{MS}: \mathrm{m} / \mathrm{z}=963\left(\mathrm{M}^{+}, 15\right), 601(20)$, 386 (100), 236 (77), 92 (95), 51 (82). Elemental analysis: Calc. for $\mathrm{C}_{58} \mathrm{H}_{50} \mathrm{~N}_{4} \mathrm{O}_{6} \mathrm{~S}_{2}$ (963.17): $\mathrm{C}=72.33, \mathrm{H}=5.23, \mathrm{~N}=$ $5.82 \%$. Found: $\mathrm{C}=72.24, \mathrm{H}=5.18, \mathrm{~N}=5.88 \%$.

\section{Results and Discussions}

The highly versatile compound N,N'-([1,1'-biphenyl]-4,4' -diyl)bis(3-oxobutanamide) (1) was prepared fro m benzidine and ethyl acetoacetate. The base-prompted reaction of the acidic methylene compound 1 with phenyl isothiocyanate in dry DMF at room temperature in basic medium led to the formation of the non-isolable intermediates 2 which underwent insituheterocyclization reaction with chloroacetyl chloride to afford the corresponding bis-thiazolidin-5-one derivative 3 (Scheme 1).

Insitu treatment of the non-isolable intermediates 2 with dilute $\mathrm{HCl}$ gave the corresponding bis-thiocarbamoyl derivatives $4 a$ and $4 b$. Refluxing of 4 with chloroacetic acid in acetic acid containing anhydrous sodium acetate afforded the corresponding bis-thiazolidin-4-one derivatives 5 . The molecular structure of 5 was confirmed by analytical and spectral data. 
Treatment of bis-thiocarbamoyl derivative $4 \mathrm{a}$ with diazotized sulphanilic acid in the presence of sodium acetate affected acetyl cleavage (Japp-Klingmann reaction type) with the formation of arylhydrazono-thiocarbamoyl derivative 6 (Scheme 2). The structure of the highly functionalizedarylhydrazono-thiocarbamoyl derivative 6 was elucidated on the basis of its elemental analysis and spectral data.

The reactivity of the methylene group in bis-thiazolidin-5-one derivative 3 and bis-thiazolidin-4-one derivative $5 \mathrm{a}$ was tested toward the azo coupling reactionwith diazonium salts. Thus, when two moles of diazotized sulphanilic acid at $0-5{ }^{\circ} \mathrm{C}$ reacted with the thiazolidinonederivatives 3 and 5 a yielded the corresponding bis-hydrazono derivatives 7 and 8 respectively. The structures of compounds 7 and 8 were assigned on the basis of their elemental analyses and spectral data.

Treatment of bis-thiazolidin-5-one derivative 3 and bis-thiazolidin-4-one derivative 5a with $p$-isopropylbenzald ehyde in ethanol/piperidine afforded the corresponding bis-(4-arylidene-thiazolidin-5-one) 9 and bis-(5-arylidene-th iazolidin-4-one) 10 in good yields. Assignment of the products 9 and 10 was based on their elemental analyses and spectral data.<smiles>Nc1ccc(-c2ccc(N)cc2)cc1</smiles><smiles>CCOC(=O)CC(C)=O</smiles><smiles>[R]NC([Y])=C(C(=O)Nc1ccc(-c2ccc(NC(=O)C(C(C)=O)=C([Y])[R])cc2)cc1)C(=O)O[R16]([R])([H])F</smiles>

2 $\mathrm{ClCH}_{2} \mathrm{COCl}$<smiles>[R]N1CC(=O)S/C1=C(/C(C)=O)C(=O)Nc1ccc(-c2ccc(NC(=O)/C(C(C)=O)=C3/SC(=O)CN3[R])cc2)cc1</smiles>

Scheme 1. Synthesis ofbis-thiazolidin-4-one derivative 3 

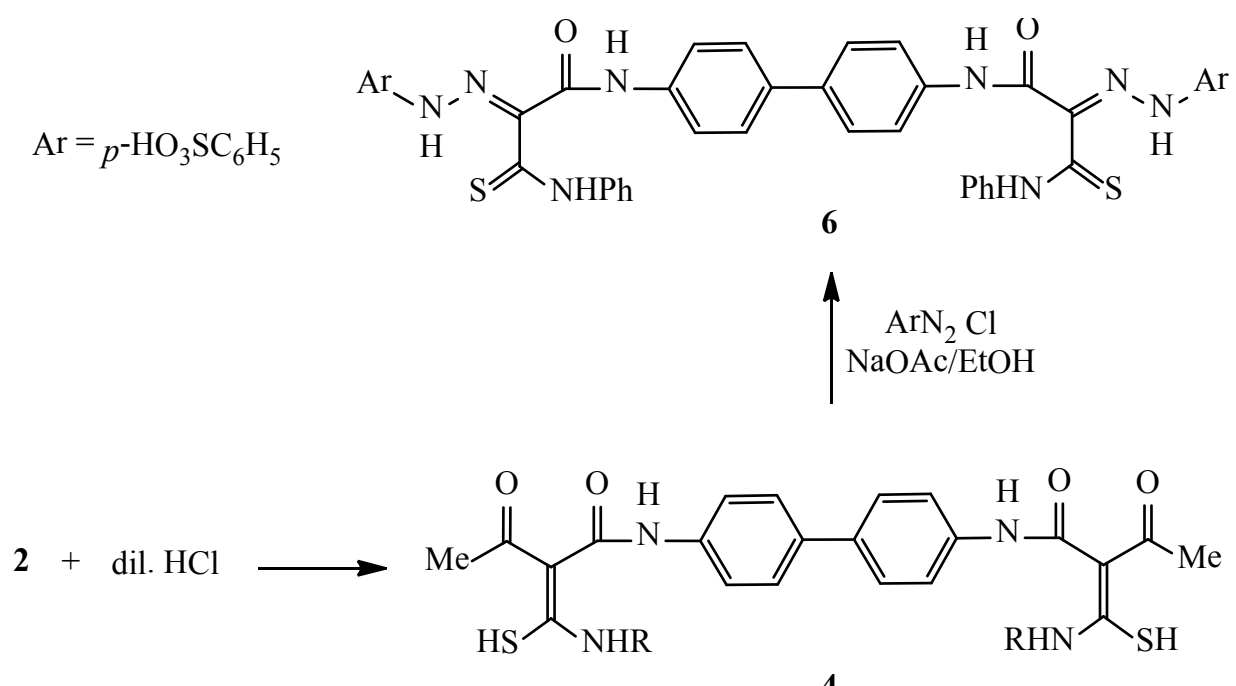

a: $\mathrm{R}=\mathrm{C}_{6} \mathrm{H}_{5}, \mathbf{b}: \mathrm{R}=\mathrm{C}_{2} \mathrm{H}_{5}$
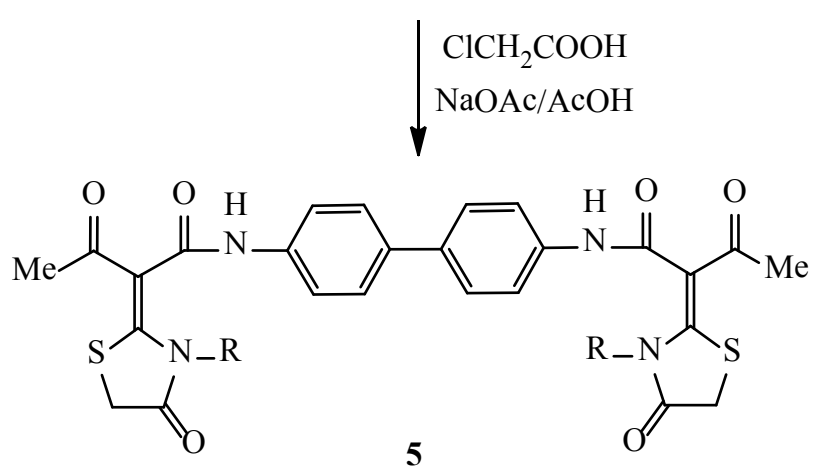

a: $\mathrm{R}=\mathrm{C}_{6} \mathrm{H}_{5}, \mathbf{b}: \mathrm{R}=\mathrm{C}_{2} \mathrm{H}_{5}$

Scheme 2. Synthesis ofbis-thiazolidin-4-one derivatives 5 and ary lhydrazono-thiocarbamoyl derivative 6

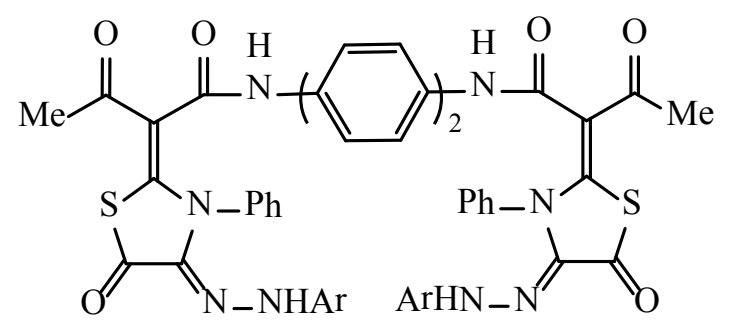

7: $\mathrm{Ar}=p-\mathrm{HO}_{3} \mathrm{~S}-\mathrm{C}_{6} \mathrm{H}_{4}$<smiles>CC(=O)C(C(=O)Nc1ccc(NC(=O)C(C(C)=O)=c2sc(=O)c(=C[Al])n2-c2ccccc2)cc1)=C1SC(=C[Al])C(=C[Al])N1c1ccccc1</smiles>

9: $\mathrm{Ar}=p^{-}\left(\mathrm{CH}_{3}\right)_{2} \mathrm{CH}-\mathrm{C}_{6} \mathrm{H}_{4}$<smiles>CCCCCCNN=C1S/C(=C(/C(C)=O)C(=O)Nc2ccc(NC(=O)/C(C(C)=O)=C3\S/C(=N\N)C(=O)N3c3ccccc3)cc2)N(c2ccccc2)C1=O</smiles>

8: $\mathrm{Ar}=p-\mathrm{HO}_{3} \mathrm{~S}-\mathrm{C}_{6} \mathrm{H}_{4}$

Scheme 3. Reactions of thiazolidin-5-one derivatives 3 and 5 a with diazotized sulphanilic acid and $p$-isopropylbenzaldehyde 


\section{Conclusions}

We have synthesized new bis-thiazolidin-5-one and bis-thiazolidin-4-one derivatives by the reaction of available thiocarbamoyl derivatives with chloroacetyl chloride and chloroacetic acid, respectively.The title compounds bis-thiazolidin-5-one and bis-thiazolidin-4-one derivatives showed high reactivity towards azo coupling reaction with diazotized sulphanilic acid and Knoevenagel reaction with 4-isopropylbenzaldehyde.

\section{REFERENCES}

[1] Gaumont, A.-C.; Gulea, M.; Levillain, J.; Overview of the chemistry of 2-thiazolines. Chemical reviews. 2009, 109, 1371-1401.

[2] Ibatullin, U. G.; Petrushina, T. F.; Leitis, L. Y.; Minibaev, I. Z.; Logvin, B. O.; Synthesis and Transformations of 4-Substituted 2-Aminothiazoles. Khimiya Geterotsikli cheskikh Soedinenii (1993) 715-718.

[3] Behbehani, H.; Ibrahim, H. M.;4-Thiazolidinones in heterocyclic synthesis: synthesis of novel enaminones, azolopyrimidines and 2-arylimino-5-ary lidene-4thiazolidinones. Molecules. 2012, 17, 6362-6385.

[4] Kumar, D.; Bux, F. B.;ParmarV.;Singh, A.; Thiazolidi.none: synthesis and biological studies.Der PharmaChemica. 2012, 4, 538-543.

[5] Hang, P. C.; Honek, J. F.; Electronic structure calculations on the thiazole-containing antibiotic thiostrepton: molecular mechanics, semi-empirical and ab initio analyses. Bioorganic and medicinal chemistry letters. 2005, 15, 1471-1474.

[6] Patel, D.; Kumari, P.; Patel, N.; Synthesis and biological evaluation of some thiazolidinones as antimicrobial agents. European Journal of Medicinal Chemistry. 2012, 48, 354-62.

[7] Beuchet, P.; Varache-Lembège, M.; Neveu, A.; Léger, J.-M. ; Vercauteren, J.; Larrouture, S.; Deffieux, G.; Nuhrich, A.; New 2-sulfonamidothiazoles substituted at C-4: synthesis of polyoxygenated aryl derivatives and in vitro evaluation of antifungal activity. European journal of medicinal chemistry. 1999, 34, 773-779.

[8] Patel, J. B.; Desai, V. A.; Synthesis of some new thiazolidinones derived from 1-p-tolylethanone and their antibacterial and antifungal activities. International Journal of Industrial Chemistry. 2011, 2, 45-51.

[9] Geronikaki, A.; Vicini, P.; Dabarakis, N.; Lagunin, A.; Poroikov, V.; Dearden, J.; Modarresi, H.; Hewitt, M.; Theophilidis, G.; Evaluation of the local anaesthetic activity of 3-aminobenzo[d]isothiazole derivatives using the rat sciatic nerve model. European journal of medicinal chemistry. 2009, 44, 473-481.

[10] Velmurugan, V.; Leelavathi, N.; Kalvikkarasi, S.; Shanmuga Priya, S.; Vijey Aanandhi, M.; Synthesis and anticonvulsant activity of thiazolidinone derivatives. International Journal of ChemTech Research. 2012, 4, 1-4.

[11] Papadopoulou, C.; Geronikaki, A.; Hadjipavlou-Litina, D.; Synthesis and biological evaluation of new thiazolyl/ benzothiazoly l-amides, deriv atives of 4-phenyl-pip erazine. II Farmaco. 2005, 60, 969-973.

[12] Kreutzberger, A.; Schimmelpfennig, H.; Antiviral Drugs, XVIII: 2-Aminothiazoles by Cleavage of the S-S-Bond of Disulfidodicarbamidine. Archiv der pharmazie. 1981, 314, 385-391.

[13] Keil, D.; Flaig, R.; Schroeder, A.; Hartmann, H.; Synthesis and characterisation of methine dyes derived from $\mathrm{N}$, $\mathrm{N}$-disubstituted 2-aminoselenazoles and some of their heterocyclic sulfur analogues. Dyes Pigments. 2001, 50, 67-76.

[14] Metwally, M. A.; Abdel-latif, E.; Khalil, A. M.; Amer F. A.; Kaupp, G.; New azodisperse dyes with thiazole ring for dy eing poly ester fabrics. Dy es Pigments. 2004, 62, 181-195.

[15] Singh, K.; Singh, S.; Taylor, J. A.; Monoazo disperse dyes - part 1: synthesis, spectroscopic studies and technical evaluation of monoazo disperse dyes derived from 2-aminothiazoles. Dyes Pigments. 2002, 54, 189-200.

[16] Yen, M. S.; Wang, I. J.; Synthesis and solvent characteristics of bishetarylmonoazo dyes derived from polysubstituted -2-aminothiophene derivatives. Dyes Pigments. 2005, 67, 183-188. 